very great indeed; but the work seems to have attained. a very high degree of accuracy. Misprints, or slips, occur in the following places : Matt. xviii 20 ; Marc. i 20 , viii $3^{6}$, xiv 43 (note, where J;0000 seems to be translated et fustibus), 72 ; Luc. ix 59 ; Jo. xiii Io (note). It would have been better if the number of the chapter had been given above each page of the Latin. It is not as easy as it should be to find one's place in the book.

The Apparatus is very full. Forty-two MSS (including seven Nestorian) are quoted, in addition to four Massoretic codices (of which one is Nestorian). The oldest of the former class belongs to the fifth century, the oldest of the latter to the ninth. The majority of the documents belong to the British Museum, but three come from the Bodleian, two from Florence, one from the Vatican, and one from Germany. The editions used are the Editio Princeps of 1555 , Schaaf's (first) edition of 1708, and the New York Nestorian edition of 1886 . Lee's edition of 1816 , the text of which is very good, is not referred to.

W. EMERy Barnes.

\title{
THE DATE OF THE EPISTLE TO THE GALATIANS.
}

I. Die Adressaten des Galaterbriefes. By Dr. Valentin Weber. (Kitz: Ravensburg, I900.)

2. Die Abfassung des Galaterbriefes vor dem Apostel-Konzil. By Dr. Valentin Weber. (Kitz: Ravensburg, I9oo.)

3. Das Datum (Apg. xiv 28) des Galaterbriefes. By Dr. Valentin Weber. (From the Theologisch-praktische Monats-Schrift. Passau : December, I 900.)

4. Die biblischen Quellen fur ein 'Leben Pauli' und der Grad ihrer geschichtlichen Glaubwïrdigkeit. By Dr. Valentin Weber. (Linz, rgor.)

THE above works by Dr. Weber, Professor of Theology at Würzburg, are dictated by a common purpose, viz. to defend the authority of the Acts of the Apostles and of the Pauline Epistles as historical documents. The supposed inconsistencies between these two sources (and in particular between Gal. ii and the Acts) have been madè the ground for discrediting either the Acts (Baur and the Tubingen School) or the Epistles (the later-chiefly Dutch-radical criticism). Dr. Weber contends that the inconsistencies are not real, but only the result of mistaken attempts at identification on the part of commentators. His own position is that the Epistle to the Galatians is addressed to the converts made on the First Missionary Journey, and was written from Antioch during the 'no little time' of Acts xiv 28, i. e. shortly before 
the Conference at Jerusalem (Acts xv). The order of the events described in Gal. i, ii (=Acts ix-xiv) is then as follows. The first visit of the Apostle to Jerusalem after his conversion is described in Gal. i 18-20 (=Acts ix 26-29). It was followed by the perod of missionary activity amongst Gentiles, at first from Tarsus (Acts ix 30 ), afterwards from Antioch (Acts xi $25-26=$ Gal. i $2 \mathrm{r}-24$ ) as the base of operations. Fourteen years after his conversion, the Apostle makes his second visit to Jerusalem.(Acts xi 30 , xii $25=$ Gal. ii $I-10$ ) along with Barnabas and Titus. The errand was twofold. He was one of the deputies chosen to convey the money collected at Antioch for the famine relief fund (Acts xi 30 ): of this it is not to his purpose to speak in Galatians, and there is only a passing reference (ii 9). But also he went up 'by revelation' (Gal. ii 2) to secure 'the Gospel which I preach to the Gentiles' against a Judaizing attack by obtaining from the 'pillar' Apostles the assurance of their support. This was effected in a private conference (Gal. ii $2 \mathrm{ff}$.). Some time after the return to Antioch St. Paul made his First Missionary Journey, in which the Galatians were twice visited (Acts xiv 2 I-23; cf. Gal. iv I3). It was followed by a renewed outbreak at Antioch of the Judaizing agitation, made more dangerous by the arrival of 'certain from James,' and the consequent attitude of St. Peter and St. Barnabas (Gal. ii i I ff.). About the same time also, the news reached St. Paul that his recent converts in Galatia were troubled by the Judaizing party; and it was this news which led him to write the Epistle to the Galatians. The opposition at Antioch came to a head at last with the definite demand that all Gentile converts should be circumcised and observe the Law of Moses. The leaders at Antioch were unable to quiet the disturbance, and therefore referred the decision of the matter to the Apostles and the mother-church at Jerusalem. Hence the Council of Acts xv. Gal. ii I ff. does not then disagree with Acts $\mathrm{xv}$, since each refers to a different occasion. The slight similarity between the two is explained by the fact that both represent stages in the history of the same controversy. Seen in this light, the supposed inconsistencies fall to the ground; and with them falls the basis of the attacks both on the Acts and on the Epistle.

What are we to say of the positions which make this reading of the history possible? They are two: viz. that the Epistle to the Galatians was (i) addressed to the converts of the First Missionary Journey, (ii) written before the Council at Jerusalem. The first position has already been widely discussed and widely accepted. As far as we have been able to find out, Dr. Weber does not make any material addition to the arguments which have already been put forward in its favour. His peculiarity lies in the combination of this with the revival 
of the theory suggested by Calvin, Beza, and adopted in the last century by Ulrich (1836) and Bottger (1837), that the Epistle was written before the Council took place ${ }^{1}$. He insists as strongly as any on the difficulties attending any attempt to identify Gal. ii I-Io with Acts xv. On the other hand, he meets and answers the objections raised against the identification of Gal. ii I-IO with the visit of Acts xi 30 , xii 25 . In both cases his arguments are strong, if not entirely convincing. Then he lays down bis two chief reasons for dating the Epistle before the Council. (I) The manner in which the Judaizing attack is delivered (according to this Epistle) points to a time before the Church had pronounced a decision such as that of the Council. Dr. Weber perhaps makes rather too much of this argument. In places he seems to imply that the decision of Acts xv 28, 29 would necessarily stop the mouth of the Judaizers at once. It is true that the language of the Epistle does at times (see e.g. the strong àvaykáfovou of vi I2) suggest an opposition which insisted on the necessity of circumcision for salvation, and that this view, actually held before the Conference (Acts $\mathrm{xv} \mathrm{r}$ ), can hardly have been openly held after it. But other passages (e.g. iii 3) favour the idea of an opposition pressing for circumcision as necessary for 'perfection' (as distinct from bare salvation): and this attitude is at least conceivable after the Conference. Dr. Weber is on surer ground when he asks: 'Why does St. Paul make no appeal or allusion either to the decisions of the Conference on the main question at issue (viz. circumcision) or to the qualifying clauses (Acts xv 20, 29)?' In view of Acts xvi 4, the most satisfactory answer to this question is certainly that which Dr. Weber gives, viz. because the Epistle was written before the Conference took place.

(2) A comparison is drawn between Galatians and the other three 'Hauptbriefe' (Romans, 1 and 2 Corinthians), as regards the method of the Judaistic opposition. Dr. Weber puts his case somewhat as follows. In Galatians, the opposition encountered is mainly concerning a doctrinal question, the pressing of circumcision on the Gentiles. There are few, if any, signs of a personal attack on the Apostle himself. But, on the other hand, in Romans and Corinthians the reply to a personal attack occupies the whole ground, while all signs of the clamour for circumcision have disappeared : the doctrinal opposition of Galatians has been meanwhle made untenable by the decision of the Conference. Dr. Weber goes so far as to say that even if we had no Acts of the Apostles, we should still have inferred from these four Epistles that some authoritative pronouncement in the sense of Acts xv

1 In England the same combination has been lately suggested (I believe independently of Dr. Weber) by Mr. Vernon Bartlet (Expositor, Oct. I899, pp. ${ }_{26}{ }_{3}$ ff., and his Apostolic Age, pp. 84 f.). 
had intervened between Galatians and the other three. Once more Dr. Weber rather forces his proof. The personal attack undoubtedly impleed in Gal. i $\mathbf{x}$ and elsewbere in the Epistle is under-estimated: Is it not the chief aim of the Apostle in cc. $i-1 i$ to show his in: dependence of all, even the very highest, human agency? Does he not use words to this effect as regards both the Gospel which he preached (i 12 ) and his Apostolic commission (i I)? Further, is it not possible that events took different courses in Corinth and in Galatia? And again, what are we to make of the reappearance of the doctrinal opposition in Phil. iii? But, once more, Dr. Weber's general conclusion is hard to shake. It is interesting to note that Dr. Hort (Judaistic Christianity, pp. 95,98, IOI) remarks upon the absence of warnings against militant Judazing doctrine in $I$ and 2 Corinthians and Romans.

Dr. Weber disposes of many possible objections to his theory. The probability of two visits to the Galatians before the Epistle is allowed on the grounds of iv 13 : but at the same time, it is shown that the second visit may be that of Acts xiv $2 \mathrm{I}-24$ i. e. during the return half of the First Missionary Journey. The chronological difficulty is also met by placing the conversion of St. Paul about the year $32-$ an early but not impossible date, in which too Dr. Weber does not stand alone.

The reader will perhaps have gathered already what is our chief ground of complaint against Dr. Weber. Everything he can lay hold of must be dragged in by the heels to add another probability. The result is that many of his arguments do not help him much. The explanation of -the 'infirmity of the flesh' as the persecution to which the Apostle was subjected; the contention that Gal. v 2 could not have been written after the circumcision of Timothy; the attempt to identify the 'revelation' of Gal. ii 2 with 2 Cor. xii I ff.: these are instances of unconvincing arguments. Fortunately, however, for his theory, Dr. Weber relies upon a cumulative proof. In spite of the weak places in the defence, the main position is a strong one.

Erklarung von Gal. ii 6a. By Dr. Valentin Weber. (Kirchheim: Mainz, 1900.)

AN interpretation of the words àmò $\delta \dot{\epsilon}$ т⿳亠丷厂

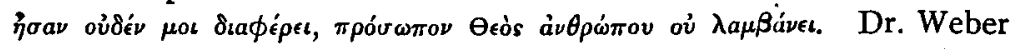
refers the $\delta$ moio to the ois of the previous verse, and makes its subject not the Apostles but the 'false brethren.' In addition, he suggests that

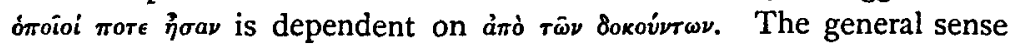
of the passage then runs: 'What reputation they might have from their connexion with (or as emissaries of) those who were held in honour (i. e. the Pillar Apostles) makes no difference to me; GoD respecteth no man's person. For to me (emphatic) those who were in honour 
added nothing in conference.' This interpretation makes the passage fit in smoothly with the context and removes the difficulty of the violent anacoluthon. But it is in its turn surrounded by difficulties more serious than the anacoluthon which it removes. The chief objection to

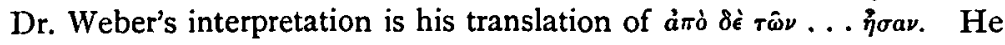
does not make it clear whether $\dot{a} \pi \delta$ is to be understood (a) locally (as infra v. I 2 rıvàs àmò 'lakíßov) 'what position they had as emissaries from those in honour,' or (b) like ík (e.g. 2 Cor. xi 26 ), 'at the hands of,' ' what position they held from those in honour.' The former may safely be set aside as impossible in view of the Greek. The latter gives a very doubtful meaning to àmó. To both it must be said that the order of the Greek is all but fatal. There are also other weak points connected with Dr. Weber's suggestion. It may fairly be urged that there is a natural and obvious connexion between doxovivw eivai $\pi$

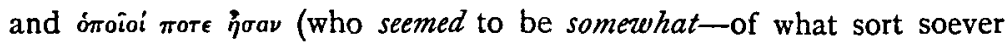
they actually were makes no difference to me). The Apostle says 'not only their reputation, but even also their actual position does not affect me--the Apostle neither of man nor by man, who received not my Gospel from man.' Dr. Weber's rendering obliterates this connexion. Again he has to make the scene shift from Jerusalem $(v v .1,2)$ to Antioch (vv. 3-6), back to Jerusalem (vv. $7 \mathrm{ff}$ ), without any indication of such changes in the text.

On the whole, Dr. Weber asks us to concede more than the traditional interpretation demands. On the one side we have a harsh anacoluthon, but not without parallel (e.g. Marc. ix 20; Rom. xvi 25-27; I Tim. i 3 ff.; I Jo. ii 24, 27 ; and just above, Gal. ii 4, 5). On the other side, an unnatural order of words; a doubtful meaning of $\dot{a} \pi \dot{c}$; an unexplained shifting of the scene; and the destruction of an obvious connexion in the words. Dr. Weber seeks throughout these first two chapters of the Epistle to make as little as possible of the differences between St. Paul and the 'Pillar Apostles.' But while we agree in refusing to take ii 6 as a piece of gratuitous sarcasm on the part of St. Paul towards the Three, we cannot help thinking that the desire to put the best possible construction on the relations between the two parties has led Dr. Weber into an untenable interpretation of this verse.

S. C. Gayford. 